\title{
A Socio-Legal Inquiry into the Perception of Divorce among Married Couples in Irhirhi Community, Southern Nigeria
}

\author{
Barr. Emmanuel Imuetinyan Obarisiagbon \\ Department of Sociology \& Anthropology, University of Benin, Benin City \\ Email: emmanuel.obarisiagbon@uniben.edu
}

Doi:10.5901/mjss.2016.v7n4p

\section{Abstract}

\begin{abstract}
The rate at which people seek for the dissolution of their marriages in Nigeria is becoming quite alarming. Why would a couple who celebrated their union with so much fanfare, pomp and pageantry suddenly find themselves incompatible? The study was carried out in Irhirhi Community, Southern Nigeria using a triangulation of the qualitative and quantitative methods. A total of four hundred and fifty respondents and thirty-five interviewees were sampled. The study used the functionalist perspective to explain the perception of married couples on the issue of divorce. The findings of this study revealed that there were several causes of divorce amongst which are childlessness, adultery, financial difficulties and incompatibility of the couples. It was also discovered that divorce does not occur at the snap of the fingers but is an accumulation of happenings which were left unattended to. Interestingly, the study found that the married couples in Irhirhi Community, Southern Nigeria are basically not aware of the existence of laws on divorce. Based on these findings, the study recommended that the Religious, NonGovernmental Agencies, the family and the mass media should wake up to their responsibilities by inculcating the right family values in their members.
\end{abstract}

Keywords: Divorce, Law, Perception, Irreconcilable differences, Adultery and Childlessness

\section{Introduction}

The celebration of marriage in Nigeria is one phenomenon that usually elicits a lot of funfair and happiness on the part of the would-be couples, their parents and friends. Older persons and religious ministers at such celebrations, usually advice the couple on how to have a blissful marriage as well as on how to handle conflicts within the home. The essence of giving such unsolicited advice is to ensure that the couples have a stress free marriage. Unfortunately, it would appear that these marriages either get too late to the couples or that they from time to time chart their own marriage prototype which in most cases result in divorce.

The incidence and prevalence of divorce in Nigeria and the world in general is quite alarming and the issue needs urgent attention. While data on divorce exist in advanced nations as depicted in Weikel and Wilson (2006) assertion that divorce in the United States of America is on the increase, the availability of authentic statistical records showing the rate of divorce in Nigeria cannot be found except on the pages of newspapers and court files if such were resolved in the law court.

Considering the psychological, social and educational implication of divorce on the couples, the child (ren) of the marriage, parents of the couples and the society in general, there is need for marriage counsellors and those at the corridor of policy making to find means of ensuring marital stability so as to avoid the constant breakages in marital relationship.

Without doubt, divorce is not usually an intended event in a family's life as each couple at marriage usually wants a healthy marital life but circumstances beyond their control tend to lead to marital breakdown. Interestingly, these circumstances do not respect social status and academic attainment of the couples.

\section{Statement}

The issue of divorce is one that has become a recurring topic in social discourse as hardly does a day go by in Nigeria without report of a broken marriage being mentioned in the print, broadcast or new mass media. All couples go into marriage with the desire to live together, procreate and enjoy the benefits of being married.

The question is, at what stage and why do couples find themselves intolerable to live together. Several reasons have been put forward by scholars as to the causes of divorce (Oforchukwu, 2010 and Adegoke, 2010). Do these apply 
to all couples irrespective of race, tribe, religion and educational attainment?

It has been observed that divorce has severe implications not just on the couples, the child (ren) of the marriage alone but also on the society in general. The effect of divorce on the society has been noted as drastic and messy (Hardon, 2004 and Katu, 2008). This therefore calls for a concerted effort at stemming the tide of this social menace.

The rate at which couples contract marriages is on the increase. Equally on the increase is the rate at which young couples walk out of their marriages by filing for the dissolution of their marriages. This is quite worrisome and calls to question whether there are legal provisions for and against divorce and whether these legal provisions are known to the public. This study therefore seeks to identify the causes, effects and the provisions of the law for and against divorce as well as examine the level of awareness of this by members of the society.

\section{Objectives of Study}

The study is designed to:

1. Examine the perception of married couples in Irhirhi Community, Southern Nigeria on the causes of divorce.

2. Investigate the perception of married couples in Irhirhi Community, Southern Nigeria on the effects of divorce.

3. Inquire into the level of awareness of married couples in Irhirhi Community, Southern Nigeria about the provisions of the law on divorce.

\section{Research Question}

1. How do married couples especially in Irhirhi Community, Southern Nigeria perceive the cause of divorce?

2. Do married couples in Irhirhi Community, Southern Nigeria perceive divorce as having consequences?

3. Are married couples in Irhirhi Community, Southern Nigeria aware of the existence of laws on divorce?

\section{Review of Related Literature}

Quite a lot of work has been done on the subject matter divorce by scholars. Interestingly, however, scholars are not agreed on a particular cause of divorce as each has tended to advance what is considered the cause. In the same vein, opinions are divided on the implication of divorce proceedings and actual divorce. Similarly, several effects of divorce have been identified by scholars and it would appear that these effects are quite damaging.

One of the factors that has been identified as one of the causes of divorce is childlessness. In Nigeria, high premium is put on the child. The child is seen as the bundle of joy for the family.

Those who do not have children in their marriage are more often than not, looked down on and talked about. Little wonder then that the rate of divorce on grounds of childlessness and barrenness as the case may be, is on the increase. Put succinctly, any marriage that is not blessed with children is considered not to have achieved its aim (Oforchukwu, 2000).

Another cause of divorce in Nigeria is adultery. The Mosaic Law and Christian religious practices frowns at divorce. The law of Nigeria particularly Section 15 (2) of the Matrimonial Causes Act (2004) has clearly spelt out grounds for the dissolution of marriages contracted under the Act. This implies that the court will and do in fact order the dissolution of marriage on grounds of adultery. Curiously, the customary law - Bini Native Law and Custom does not consider adultery committed by a man as a ground for divorce (Obarisiagbon, 2009). Little wonder therefore, that an action in a customary court in Benin City for the dissolution of marriage will fail as the customary court cannot hold a Bini man as committing adultery. Adultery can only be committed by a Bini woman.

Adultery is an act of sexual intercourse between a married man and a woman who is not his wife. It can also be seen as an act of sexual intercourse between a married woman and a man who is not her husband. It is usually considered a very serious offence, an abomination particularly when it is committed by a woman.

Financial difficulties have been identified as another cause of divorce amongst couples. Though this is not a ground for divorce in the Matrimonial Causes Act but more often than not, lack of finance tends to lead to irritation. Even the presence of money can also be a source of misunderstanding if either of the couple is extravagant or stingy, that could be a source of divorce if the other party is not mature in handling it.

Another cause of divorce amongst married couples is irreconcilable differences. It is a fact of life that disagreement and quarrels do exist in relationships and marriages however, when this becomes the order of the day, either of the spouses could file for a divorce or walk out of the marriage. The Matrimonial Causes Act (2004) considers this a ground for the dissolution of marriages and the court has in a plethora of cases applied this rule in ordering the dissolution of 
marriages. Quarrels, misunderstandings and strife are bound to occur and usually create friction among couples. As Igbinovia (2015) puts it, quarrelling is unhealthy in a relationship and poses a big problem in married life. If this is left unattended to, the end product is usually divorce.

It is needful to state here that divorce also occurs due to technological changes in form of innovations. Regrettably, these innovations could pose serious dangers on marriages (Owusu-Dempah, 2007). One area where this has become pronounced is the use of the internet and all forms of social media. Marriages are being hunted down due to the fact that couples no longer spend quality time with each other, rather; the social media has become their companion. The result of this is that either of the party especially the one that is not into the social media feels abandoned, uncared for or lonely; with this, nagging not only sets in but may be a precursor to divorce.

Research has shown that the age at which a couple is when a marriage is contracted is a major determinant on marital stability and divorce. Kornblum (2001) observed that women who marry while still in their teens are twice as likely to divorce as women in their 30's but those who marry in their 30's are half again as likely to divorce as those who married in their 20's. This implies that higher ages at marriage are typically thought of as an indicator of female autonomy.

In Nigeria, studies have revealed that the educational attainment of a couple is positively associated with the dissolution of marriages (Isiugo-Abanihe, 1998 and Adedokun, 1998). To Adedokun, the higher the level of education, the higher the incidence of divorce among educated women of reproductive age. They are more likely to embrace new ideas about marriage as well as the fact that increasing participation of educated women in the labour force may have reduced the extent to which they are dependent on their husbands. Isiugo-Abanihe's (1998) study revealed that the association between female education and divorce is strong. This is because, the influence of education appears to be non lineal with the lowest divorce rates observed among uneducated women and the highest educational groups.

Religious affiliation has been found to be a factor in the explanation of divorce among Nigerian women. IsiugoAbanihe, (1998) and Tilxon and Larsen (2000) have found that marriages contracted under Islamic religion are more stable than those contracted under the Christian faith. It would appear that the rigorous Islamic religious practices, customs and Laws have in no small measure helped to act as checks to divorce among Muslims.

\section{Consequences of Divorce}

The rising increase in divorce rate among married couples in Nigeria has been a major source of concern to scholars especially against the background of the dire consequences it has on not just the couple but the society in general.

Studies have shown that divorce affects the well-being of adults as it is often associated with sadness, upset and feeling of loss (DiPrete and McManus, 2000, McManus and DiPrete, 2001, Amato, 2000 and Uunk, 2004). A lot of women in Nigeria depend so much on their husbands for economic survival and are usually worse hit when there is a dissolution of their marriage as they are not only left high and dry but do not really know where to pick up their lives from. To feed, clothe and house themselves become really difficult and they have to resort to family, friends and well wishers for assistance.

Without mincing words, one of the effects of divorce is its devastating nature on children irrespective of their age as they navigate their way towards adulthood. Youths are highly insecure perhaps even more so than when they were children; they need the anchor of family stability. At the time in life when youths are learning to gorge mature friendship, divorce teaches them to be skeptical of such values as trust, loyalty and love. Later as adults, they may avoid close relationships altogether (Newman, 1991). While it is common for children of all ages to act out their pains, adolescents are more likely to do so in dangerous ways including delinquencies, alcohol and drug abuse. This gives the impression that children of divorced parents may be morally defective, lawless and fear neither God nor man (Harden, 2004).

It has been observed that divorce sometimes leads to psychological and mental breakdown on the part of the divorcees and that most divorcees either live a lonely life or are in the extreme by living a reckless life. Women particularly, find it psychologically and mentally unnerving when faced with the stark reality of divorce as they had put in everything in their lives into the marriage and see life as coming to an end when there is dissolution of their marriage (Igbinovia, 2015).

On the social sphere, at marriage a couple wears a new garment. The women are seen in Nigeria as "Madam", "Mrs." While the men are now respected and seen as responsible persons who can be entrusted with positions in the society. This clothes of respect and responsibility vanishes the moment a marriage is dissolved. The Madam and Mrs. vanish into thin air and the men can no longer be entrusted with sensitive positions; in the Christian religion, these ones cannot be ordained ministers in the church. 


\section{Legal Explanation of Divorce}

According to the Black's Law Dictionary (2004) the term divorce imports the dissolution of a marriage relations between husband and wife, that is, a complete severance of the tie by which the parties were united. This severance of the ties by the parties can only take place upon the occurrence of an existing fact. In Nigeria, these facts are well spelt out in Section 15 (2) of the Matrimonial Causes Act, CAP M7 (2004). This section provides that before the dissolution of marriage, one or more of the following facts must be established:

a. That the respondent has willfully and persistently refused to consummate the marriage;

b. That since the marriage, the respondent has committed adultery and the petitioner finds it intolerable to live with the respondent;

c. That since the marriage, the respondent has behaved in such a way that the petitioner cannot reasonably be expected to live with the respondent;

d. That the respondent has deserted the petitioner for a continuous period of at least one year immediately preceding the presentation of the petition;

e. That the parties to the marriage have lived apart for a continuous period of at least two years immediately preceding the presentation of the petition and the respondent does not object to a decree being granted;

f. That the parties to the marriage have lived apart for a continuous period of at least three years immediately preceding the presentation of the petition;

g. That the other party to the marriage has, for a period of not less than one year failed to comply with a decree or restitution of conjugal rights made under this Act;

$h$. That the other party to the marriage has been absent from the petitioner for such a time and in such circumstances as to provide reasonable grounds for presuming that he or she is dead.

The courts have in several cases interpreted Section 15 (2) of the Matrimonial Causes Act, 2004 in dissolving a marriage. The evidence of the existence of one of the above facts is enough for a divorce to take place, little wonder therefore that the sole ground that the marriage has broken down irretrievably was relied upon by the court in ordering a dissolution of marriage in the case of Anioke v. Anioke (2013) AA FWLR pt 658 p 975 at 986 para g. This judicial pronouncement is further given credence to in the case of Okoro v. Okoro (2011) ALL FWLR pt 572 p 1749 at 1773 para $\mathrm{g}$-h. It is clear from the above that divorce has statutory favour and can be ordered by a court of competent jurisdiction if the marriage was contracted under the Act. However, if a marriage was contracted under Native Law and Custom (Customary Law) with payment of a bride price, such a marriage cannot be determined by the High court instead, it is the customary court or district court as the case may be that can order the dissolution of the marriage; curiously, on any of the grounds as stated in Section 15 (2) of the Matrimonial Causes Act.

It would appear that the law recognizes the fact that a child/children in the marriage are more likely to suffer when there is a divorce hence, it has made provision for the interest and welfare of a child. The determination of the welfare of a child is a composite of many factors. Considerations such as emotional attachment to a particular parent, mother or father, the inadequacies of facilities such as educational, religious or opportunities for proper upbringing are matters which may affect the determination of who should have custody of the child/children after divorce. The view that the interest and welfare of a child should be paramount in the mind of the court when granting the dissolution of marriage and custody of the child was noted and relied upon in the cases of Obajimi v. Obajimi (2012) ALL FWLR pt 649 p 1168 and Odusote v. Odusote (2013) ALL FWLR pt 668 and Okoro v. Okoro (2011) ALL FWLR pt 572 p 1749.

The law is also very clear on what happens to the wife and child of the marriage after divorce. The provision of Section 70 of the Matrimonial Causes Act is very apt here:

a) Subject to this section, the court may, in proceedings with respect to the maintenance of a party to a marriage, other than proceedings for an order for maintenance pending the disposal of proceedings, make such orders as it thinks proper, having regard to the means, earning capacity and conduct of the parties to the marriage and all other relevant circumstances.

b) Subject to this section and to rules of court, the court may, in proceedings for an order for the maintenance of a party to the marriage, pending the disposal of proceedings, make such order as it thinks proper having regard to the means, earnings capacity and conduct of the parties to the marriage and all other relevant circumstances.

c) The court may make an order for the maintenance of a party notwithstanding that a decree is or has been made against that party in the proceedings to which the proceedings with respect to maintenance are related.

d) The power of the court to make an order with respect to the maintenance of children of the marriage shall not be exercised for the benefit of the child who has attained the age of twenty-one years unless the court is of 
the opinion that there are special circumstances that justify the making of such an order for the benefit of that child.

This section has been judicially interpreted in the cases of Akinboni v. Akinboni (2002) ALL FWLR pt 76 p 930. In sum, it is glaring from the foregoing that the law has prescribed grounds that must be satisfied before a divorce can be granted by a court. Similarly, the law recognizes the interest and welfare of the child and the wife of a marriage upon its dissolution. What is worrisome however is that if this provision exists, why are children of failed marriages prone to hazards and delinquent behaviours? Similarly, why do divorcees' well-being nose-dive when the marriage breaks down?

\section{Theoretical Framework}

For this study, the functionalism school of thought was adopted in the explanation of the topic under investigation.

\subsection{Functionalism}

The structural functionalism theory is associated with the works of Durkheim (1897), Merton (1968) and Parson (1951). The basic assumption of the theory sees the society as a living organism made up of component parts, which function harmoniously for the survival of the whole system. If any part fails to contribute to an identifiably useful function, neither does it promote value consensus among members of the society - it will not be passed on from one generation to the next.

Functionalist theorists emphasize the two concepts of structure and function. Indeed, the model is often called structural functionalism rather than just functionalism. The structures are the various parts of the system. In the case of the society, the principal structures usually are considered to be the society's institutions - family, government (Executive, Legislature and Judiciary), economy, religion and educational system; analysis focused upon the inter-relations among these institutions. Each structure and each part within the larger structure is conceived to have a function in assisting the society to operate and in preserving its stability.

The basic tenets of structural functionalism include the following: firstly, it entails interaction among various parts within the system. What this means, is that, social phenomenon can be explained in terms of the part they play in the existence and survival of the larger society. Furthermore, there is inter -dependence of various parts within the system. This means that the function of a part of a system usually affects the system as a whole. Moreover, there is the need for the system to maintain equilibrium in order to survive. This means that the social system tend towards equilibrium. That is, when one variable of the system changes in magnitude or in quality, the other variables are subjected to strains and are transformed. As a result, the system changes its pattern of performance and the dysfunctional components are disciplined by a regulatory mechanism and the equilibrium of the system is re-established.

Malinowski (1944) saw functionalism in terms of the postulate of universal functionalism, which rests on the assumption that any and in fact every continuing social pattern or custom must have positive functions to the maintenance of the established ways of life and therefore to the welfare of members of the society. He argued that every custom, material objects, ideas, beliefs etc fulfills some vital functions, has some tasks to accomplish and represents an indispensable part within a working whole.

RadCliffe - Brown (1944) on the other hand, developed the postulate of functional unity. His argument is that the function of a particular social usage is the contribution it makes to the total social life as the functioning of the total system. This view implies that a social system has a kind of unity which is referred to as functional unity. That is, a condition in which all parts of the social system work together with a sufficient degree of harmony or internal consistency.

Functionalism is seen as the main theoretical framework for the system approach and views the social system as possessing inevitable sub-systems or institutions that exist due to their functions for the sustenance and the survival of the system. Parsons popularized the concept of functionalism in sociology. He observed that a social system consists of plurality of individual actors interacting with each other in a defined and structured manner to meet certain functional prerequisites (Haralambos and Holborn 1995). Parsons identified Adaptation, Goal attainment, Integration and Latency as the four functional prerequisites that are imperative for the survival of any system and the function of any part of the system is its contribution in meeting the functional prerequisite.

The marriage institution is a unit, a structure or an institution within the system. Whatever happens in the marriage institution has an overriding effect on the other units of the system. In the same vein, happenings or occurrences in other units of the system in no small measure play a decisive role in the stability or otherwise of the marriage institution. The presence or absence of money (economic institution) has been found to be a cause of the increasing rate of divorce in Nigeria. Similarly, emphasis on prosperity amongst preachers of the gospel of Christ (religious institution) rather than on 
holiness and sanctity of marriage has in no small ways weakened the marriage institution, thus leading to the alarming rate of divorce.

It must also be pointed out that the legal institution tacitly approves of divorce as long as certain criteria are met. These have also encouraged divorce in the Nigerian society. In sum, a disequilibrium in any unit of the social system invariably leads to an increase in the divorce rate in the society.

\section{Methodology}

Data for this study was collected through a combination of quantitative and qualitative methods. Fieldwork started with the qualitative aspect of the study which provided important insight for the investigation of the study. As it is common practice in most studies using triangulation, qualitative data are immensely important and most precede the survey method in order to facilitate the design of the questionnaire.

Qualitative data for the present analysis was elicited though thirty-five (35) in- depth interviews which employed the purposive sampling method while the questionnaire was used for the quantitative method. A total of four hundred and fifty (450) questionnaires were administered out of which four hundred and thirty were returned for analysis. This however represents a return rate of $95.8 \%$ and is considered significant. The respondents were selected by simple random from the study area.

The quantitative data was edited and cleaned to eliminate inconsistencies which could undermine the validity of the data. A descriptive analysis of data was undertaken using frequency distribution. While the qualitative data was analyzed using a manual content analysis. The procedure began with a transcription and translation of a tape recorder of the IDI'S. This was thereafter followed by the examination and isolation of various responses that were relevant to the study objectives.

\section{Results and Discussions}

Table 1: Percentage distribution of respondents by selected socio-demographic characteristics.

\begin{tabular}{|c|c|c|}
\hline CATEGORIES & FREQUENCY & PERCENTAGE \\
\hline \multicolumn{3}{|l|}{ AGE } \\
\hline $25-29$ & 82 & 19.06 \\
\hline $35-44$ & 206 & 31.3 \\
\hline $45-54$ & 112 & 26.04 \\
\hline $55-64$ & 18 & 2.6 \\
\hline 64 and above & 12 & 0.31 \\
\hline \multicolumn{3}{|c|}{ EDUCATIONAL LEVEL } \\
\hline Primary school & 7 & 1.62 \\
\hline Secondary School & 122 & 28.37 \\
\hline University & 301 & 70 \\
\hline \multicolumn{3}{|l|}{ RELIGION } \\
\hline Christianity & 403 & 93.72 \\
\hline Islam & 2 & 0.46 \\
\hline A.T.R. & 25 & 5.81 \\
\hline \multicolumn{3}{|l|}{ OCCUPATION } \\
\hline Applicants & 6 & 1.39 \\
\hline Artisans & 18 & 4.18 \\
\hline Farmers & 30 & 6.97 \\
\hline Public Servants & 268 & 62.32 \\
\hline Business & 108 & 25.11 \\
\hline \multicolumn{3}{|c|}{ DURATION OF MARRIAGE } \\
\hline $0-9$ & 86 & 20 \\
\hline $10-19$ & 202 & 46.97 \\
\hline $20-29$ & 75 & 17.44 \\
\hline $30-39$ & 57 & 13.25 \\
\hline $40-49$ & 8 & 1.86 \\
\hline 50 and above & 2 & 0.46 \\
\hline
\end{tabular}

Source: field work, October - December, 2015. 
Table 1 displays information on selected demographic variables of respondents. About $19.06 \%$ of the respondents were between $25-34$ years of age, while $47.90 \%$ and $26.04 \%$ were between $35-55$ years and $45-54$ years of age respectively. $4.18 \%$ and $2.79 \%$ fell into the age bracket of $55-64$ years and 64 years and above years respectively. This shows that many married couples within the age bracket of 35-44 years were more accessible.

As expected, a large majority of the respondents were university graduates representing $70 \%$. This is to be expected considering the fact that more people gain admission into university these days. $1.62 \%$ of the respondents had primary education while $28.37 \%$ of the respondents had secondary education.

Furthermore, $93.72 \%$ of the respondents were Christians, while $0.46 \%$ and $5.81 \%$ were Muslims and adherents of Traditional Religion respectively. The high percentage of the respondents being Christians is perhaps due to the fact that Irhirhi Community which is the study area is situated in the southern part of Nigeria which is predominantly Christian.

It was also observed that $1.39 \%$ and $4.18 \%$ of the respondents were applicants and artisans respectively while $6.97 \%$ and $62.32 \%$ were farmers and public servants respectively. Similarly, $25.11 \%$ were into business. As can be gleaned, the respondents in the public service were more accessible for this study due largely in part to the fact that they know the import of scientific research.

Table 2:

\begin{tabular}{|l|c|c|}
\hline CAUSES OF DIVORCE & FREQUENCY & PERCENTAGE (\%) \\
\hline Childlessness & 110 & 25.6 \\
\hline Financial difficulties & 45 & 10.5 \\
\hline Adultery & 93 & 21.6 \\
\hline Lack of communication & 53 & 12.3 \\
\hline Irreconcilable differences & 129 & 30 \\
\hline & 430 & 100 \\
\hline
\end{tabular}

Source: field work, October - December, 2015.

From table 2, the result revealed that there are various causes of divorce among married couples in Irhirhi community. From the table, $30 \%$ of the entire respondents opined that irreconcilable differences is the main cause of divorce followed by $25.6 \%$ who hold childlessness as a cause of divorce. Adultery has $21.6 \%$ while lack of communication has $12.3 \%$ and the least was financial difficulties with $10.5 \%$ respectively.

This view is further collaborated by the observation made by one of the interviewees when he stated that:

"My younger sister was living happily with the husband untilPower Holding Company of Nigeria (PHCN) was sold to private investors who during re-organization laid off my brother-in-law. You won't believe me, within six months, the man became a nag due to the fact that he had no more money and in all honesty, my sister was not tolerant and the marriage broke down completely".

Another respondent was very blunt as to the cause of divorce:

"Did I marry a man? If a woman cannot conceive and bear me children, of what use is it keeping her in the house? For me, three years without a child, I will ask the woman to leave as I cannot be a laughing stock before my peers."

\begin{tabular}{|l|c|c|}
\hline CONSEQUENCES OF DIVORCE & FREQUENCY & PERCENTAGE (\%) \\
\hline Leads to juvenile delinquency on the part of the children of the marriage & 146 & 33.94 \\
\hline Leads to a down turn in the economic well-being of the women. & 183 & 42.95 \\
\hline Leads to psychological and mental breakdown of the divorcees. & 101 & 23.48 \\
\hline Total & 430 & 100 \\
\hline
\end{tabular}

Source: Field work: October-December, 2015

From table 3 above, the result shows that there are various consequences of divorce. The table shows that $33.95 \%$ of the entre respondents stated that divorce leads to juvenile delinquency on the part of the children of the marriage followed by $42.55 \%$ who hold that divorce leads to a down turn in the economic well-being of the women while $23.48 \%$ held that divorce leads to psychological and mental breakdown of the divorcees. This finding is given credence to by the work of 
DiPrete \& McManus, (2000), McManus \& Diprete (2001), Amato (2000) and Uunk (2004) when they observed that a lot of women depend so much on their husbands for economic survival and ae usually worst hit when there is a dissolution of their marriage as they are left high and dry. This view is further collaborated by the observation of one of the interviewees when he stated that:

"I constantly pray to God for my marriage each time I see my sister whose marriage packed up four years ago. She's not only a shadow of herself but lives like a wretch and like one who has mental problems."

This finding is further collaborated by the views of another IDI respondent:

"Divorce is not good. My neighbour's children have not been the same since their mother left. They drink, smoke and even bring small small girls into the house during school hours".

The work of Harden (2004) supports the finding of this study when he noted that the children of divorced parents may be morally defective, lawless and fear neither God nor man.

Table 4:

\begin{tabular}{|c|c|c|}
\hline AWARNESS OF LAWS OF DIVORCE & FREQUENCY & PERCENTAGE (\%) \\
\hline NO & 344 & 80 \\
\hline YES & 86 & 20 \\
\hline Total & 430 & 100 \\
\hline
\end{tabular}

Source: Field work: October -December, 2015

Table 4 above indicates that $80 \%$ of the entire respondents are not aware of laws on divorce in Nigeria while only $20 \%$ are aware. This finding is supported by the views of one of the interviewees who stated in clear words:

"If not that you are saying that there are laws on divorce, I would have said I have not heard it. Frankly, even though I am an educated person, I have not heard or seen where the laws on divorce are written".

\section{Suggestions}

Based on the findings of this study, the following suggestions are hereby put forward:

$>$ The religious bodies, families should try to inculcate family values in their adherents and members. The sanctity of marriage must be told members and since the family is a basic unit of socialization, it will do well to stress the effects of divorce. Pre-marriage counseling should be a pre-requisite for joining couples by religious bodies.

$>$ Non-Governmental Organizations can also play a vital role in this respect as factors that tend to lead to divorce can be highlighted in workshops and seminars and ways of surmounting them, laid bare. Divorce does not occur accidentally, it is premeditated upon and there is usually a build up of several variables towards it.

$>$ The mass media should also be sensitive to the menace of this social problem. Public enlightenment on how to live a healthy marital life can be aired both in the radio and Television. Besides, drama and play-let depicting the causes of divorce and the grave consequences should be showed.

$>$ The mass media should make people know that legally, divorce has implications and the enlightenment should be that it is better to stay married to avoid issues of alimony and maintenance.

\section{Conclusion}

Divorce is a social problem that has legal implications. The rate at which people go into marriage and the fanfare that goes with it makes one to wonder why in some cases under two years, some couples come approaching the court for a dissolution of their marriages. It is glaring from this study that they are either immature, intolerable and lack wisdom in handling little strife and rifts that are commonly associated with marriage or that they have irreconcilable differences

The study has revealed that divorce is not only psychologically and mentally disturbing but that several social consequences are associated with it. 

divorce.

The study concludes that there is the need for people to be enlightened on the legal implications of marriages and

\section{References}

Adedokun, O.A. (1998). Widowhood, divorce and waiting time: A neglected aspect of nuptiality studies in Nigeria. Nigerian Journal of Social Work Education, 2 (2): 38-54

Adegoke (2010) Family Structure and Prevalence of Behavioural Problems among Nigerian Adolescents. The Counselor 17 (2) 154-161 Akinboni v. Akinboni (2002) ALL FWLR pt 76 p 930.

Amato, P. R. (2000). The Consequences of divorce for adults and children. Journal of Marriage and the Family 62 (6): $1269-1287$

Anioke v. Anioke (2013) AA FWLR pt 658 p 975 at 986 para g.

Black's Law Dictionary (2004)

DiPrete, T.A. \& McManus, P.A. (2000). Family change, employment transitions and the welfare state: household income dynamics in the United States and Germany. American Sociological Review 65 (3): 343-370

Durkheim, E. (1897). Suicide; A Study in Sociology, New York; Free Press.

Harden (2004). Learning under stress: Children of single parents and the schools. Metuchen, NJ: Women's Action Alliance and the Scarecrow Press, Inc.

Haralambus M. and Holborn M. (2004).Sociology Themes and Perspectives. Harper Collins Publishers, London. P.xiv

Igbinovia, P. (2015). Causes and effects of Divorce in Benin Metropolitan Area. An unpublished M.sc project proposal presented at the Department of Sociology, University of Benin, Benin City.

Isiugo-Abanihe Uche (1998). Stability of Marital Unions and Fertility in Nigeria. Journal of Biosocial Science, 30: 33-41

Katu (2008). Broken Family Structure Leads to Educational Difficulties for Children. Journal of Educational Psychology. 27, 70-80

Kornblum, W. (2001). Marriage and Divorce. Sociology in a Changing World. Orlando: Harcourt Brace and Company

Malinowski, B. (1944) A Scientific Theory of Culture and other Essay. North Carolina, The University of North Carolina press.

Matrimonial Causes Act, CAP M7 Laws of Federation of Nigeria (2004)

McManus, P.A. \& DiPrete, T.A. (2001). Losers and winners: the financial consequences of gaiuaseparation for men. American Sociological Review 66 (2): 246-268

Merton R.K. (1968). Social Theory of Social Structure, New York, Free press.

Newman, (2009). Children from broken homes lagging behind. Journal of Marriage and Family, 60 (1), 101-105

Obajimi v. Obajimi (2012) ALL FWLR pt 649 p 1168

Obarisiagbon, E.I. (2009) "Constitutionality of the Doctrine of Igiogbe in Nigeria". Benin journal of Social Sciences Vol. 2 No. 1 pp $42-48$

Odusote v. Odusote (2013) ALL FWLR pt 668

Oforchukwu (2010). Perceived Impact of Divorce and Geographical Separation of Couples on Bullying Behaviour of In-School Adolescents in Nigeria. Journal of Emerging Trends in Economic and Management Science. Vol.5 (2) 138-143

Okoro v. Okoro (2011) ALL FWLR pt 572 p 1749 at 1773 para g-h.

Owusu-Bempah, K. (2007). Children and separation: Socio-genealogical connectedness perspective. New York, NY: Routledge.

Parsons, (1951). The Social Structure. London. The Free Press of Glencoe.

Radcliffe -Brown (1944). On Social Structure. Journal of the Royal Anthropological Institute of Great Britain S/ Ireland 70 (1)

Tilson, D. \& Larsen, U. (2000). Divorce in Ethiopia: The impact of early marriage and childlessness. Journal of Biosocial Science, 32 (1): 355-372

Uunk, W. (2004). The economic consequences of divorce for women in European Union: the impact of welfare state arrangements. European Journal of Population 20 (3): 251-285

Weikel and Wilson Goode, M., Maas, C. \& Meeus, W. (2006). Family structure and behavior of adolescents and young adults: A growthcurve study. Journal of Youth and Adolescence, 34 (4), 401-417 